Original article

\title{
Perceived synergy between deforestation and/or forest degradation and climate variability and change in the Ejisu-Juaben Municipality, Ghana
}

\author{
Emmanuel Mawuli Abalo1*, Prince Peprah ${ }^{1}$, Divine Odame Appiah¹, Belinda Serkyiwah Asante \\ Sarpong1, Godfred Amankwaa², Yagah Nakoja ${ }^{3}$ \\ ${ }^{1}$ Department of Geography and Rural Development, Kwame Nkrumah University of Science and Technology, Kumasi, Ghana \\ ${ }^{2}$ School of Geography and the Environment, University of Oxford, South-Parks Road Oxford OX1 3QY, GB \\ ${ }^{3}$ Center for Climate Change and Sustainable Development, University of Ghana Business School, Legon \\ E-mail address ( ${ }^{*}$ corresponding author): eabalo92@gmail.com
}

\begin{abstract}
Perceptual studies on the environment and natural resources are important, if unsustainable use of these resources is to be abated. This paper unravels the hitherto unknown drivers of deforestation and/or forest degradation, and the causes of climate variability and change (CVC), by assessing their synergy based on participants self-reported cases in the Ejisu-Juaben Municipality, Ashanti Region, Ghana. Drawing on the criterion and simple random sampling techniques to sample 360 respondents from 4 different communities and adopting the empiricist paradigm to derive trends and patterns in responses, this study demonstrated the bi-directional association between forest degradation and climate change. Results suggested that participants across the various socio-economic status fields were adequately informed, and knowledgeable about changes in climatic variables. Participants' perceived the loss of forest, extinction of tree species and changing forest to savanna lands as indications of deforestation. Respondents with basic education and/or high school education adequately predicted that CVC factors influence decisions regarding forest removal compared with the uneducated. Removing one hectare of vegetation cover change per year (being it an increase or decrease in the area) (1 ha/year+/-/) or about three hectares (3 ha/year+/-), at a rate of $60 \%$, and forest cover at rates of $57 \%$ were perceived as significant drivers of CVC. In recommendation, policies targeted at reducing forest degradation and deforestation and contributing to the fight against CVC in the Municipality should henceforth take into consideration the opinions of the indigenes in addition to scientific evidence in order to ensure the effectiveness of such policies.
\end{abstract}

KEY WORDS: perception, climate variability and change, deforestation, Ejisu-Juaben Municipality

ARTICLE HISTORY: received 10 October 2017; received in revised form 28 November 2017; accepted 6 December 2017

\section{Introduction}

Aside from the economic, environmental and sociocultural benefits derived from forests (BLAY ET AL., 2007), the fight against climate change is greatly enhanced when the forest ecosystem is preserved (CANADELL \& RAUPACH, 2008; RAHMAN \& ALAM, 2016). Globally, terrestrial forest ecosystems sequester nearly 3 billion tons of anthropogenic carbon every year (CANADELL ET AL., 2007). Also, about 4 billion hectares of forest ecosystems store large reservoirs of carbon which is more than double the amount of carbon in the atmosphere
(FAO, 2006; SABINE ET AL., 2004). Currently, billions of tons of global $\mathrm{CO}_{2}$ are absorbed by forests yearly and this medium will be worth hundreds of billions of dollars should an equivalent sink be created in other ways (CANADELL \& RAUPACH, 2008).

Over the past half-century, studies on climate change have revealed that the phenomenon negatively affect different aspects of the forest ecosystem: tree growth and dieback, invasion of invasive species, species distributions and migrations, changes in seasonal patterns in ecosystem processes, demographics, and even species extinctions (IPCC, 2007; LOCATELLI ET AL., 
2008; SEPPÄLÄ ET AL., 2009). A look at the global statistics presents a gloomy picture. For instance, the World Bank suggested that of the 1.6 billion people dependent on forest resources (about 350 million people are considered highly forestdependent), the people who are totally dependent constitute 60 million indigenes (WORLD BANK, 2008) who use forest resources for their livelihood activities. Reportedly, the heavy dependence on natural resources, coupled with the weak adaptive mechanisms of the least developed countries (LDCs) makes them vulnerable to the brunt of climate change (FAO, 2007): increasing temperature, prolonged droughts, sea level rise, intermittent and unpredictable rainfall patterns and flooding (AYERS \& HUQ, 2008; ROY \& AVISSAR, 2002; OYAMA \& NOBRE, 2003).

Deforestation and/or forest degradation and climate variability and change (CVC) are synergistically related (CHRISTENSEN ET AL., 2007; BETTS ET AL., 2004; BUSH ET AL., 2004; MALHI ET AL., 2008; SÁNCHEZ-CortÉS \& CHAVERo, 2011). On the one hand, reducing deforestation is a cost-effective contribution to climate protection (CANADELL ET AL., 2007; FAO, 2006; RAMANKUTTY ET AL., 2007). A fifty percent reduction in deforestation by 2050, and stopping deforestation when countries reach $50 \%$ of their current forested area, would avoid $\mathrm{CO}_{2}$ emissions equivalent to $50 \mathrm{Pg} \mathrm{C}$ (GULLISON ET AL., 2007). Significantly too, the likely success of offsetting about 2 to $4 \%$ of $\mathrm{CO}_{2}$ emissions is to avoid deforestation (CANADELL ET AL., 2007; RAUPACH ET AL., 2007; BAKER ET AL., 2004), and tropical regions account for $65 \%$ of the total offset (METZ ET AL., 2007). On the other hand, climate variability and change regimes affect forests through alterations in disturbance regimes which result in clearing large tracts of forested areas for other land uses (FRANKLIN ET AL., 1992; DALE ET AL., 2000).

Although 1.6 million hectares of forest reserves were gazetted in the High Forest Zone (HFZ) in the 1920s in Ghana (WAGNER \& COBBINAH, 1993; ODURO ET AL., 2012), excessive harvesting of logs over and above the annual allowable cut (AAC), reduction in standing volumes of tree species, dwindling resource bases, species depletion and loss of biodiversity at an "alarming rate", characterizes the forest ecosystems of Ghana (REPETTO, 1988, 1990; HAWTHORNE, 1989; IUCN, 2006; MinistRY OF LANDS AND NATURAL RESOURCES, 2012; BROWN ET AL., 2016). Though the forest loss has been attributed to agricultural changes (ABBIW, 1990; WAGNER \& COBBINAH, 1993; APPIAH, 2001), recent studies suggest that other driving forces and factors contribute to the "alarming deforestation" witnessed across the length and breadth of the country (APPIAH ET AL., 2009; BOUCHER ET AL., 2011; HosonUmA ET AL., 2012). Some of these driving forces and factors are logging, unsustainable farming, annual bushfires, surface mining and infrastructural development, of which deforestation, or forest degradation, stands tall (PEPRAH ET Al., 2017; APPIAH ET AL., 2009; HALL \& SWAINE, 1981). Underlying these driving forces are forest policy failures, unrealistic forest fee regimes, external prices of timber and weak institutional structures (APPIAH ET AL., 2009; ALSTON ET AL., 2000; PRAH, 1997).

The continual loss of forest is worrying as it has been identified with (i) decreased cloudiness and increased insolation, (ii) increased land surface reflectance, approximately offsetting the cloud effect (BALA ET AL., 2007), (iii) changes in the aerosol loading of the atmosphere from a hyperclean "green ocean" atmosphere to a smoky and dusty continental atmosphere that can modify rainfall patterns (ANDREAE ET AL., 2004, pp. 169), and (iv) changes in surface roughness (and hence wind speeds) and the large-scale convergence of atmospheric moisture that generates precipitation (BETTS ET AL., 2004).

An assessment of the degradation of natural resources at the international and national scales are mostly focused on the expert opinions of organizations (OLDEMAN ET AL., 1991; UNEP, 1997), to the neglect of the perceptions of forest fringe indigenes, who directly utilize and manage the earth's resources. Though the perception of indigenes on degradation activities are divergent from the scientific stand point due to the criteria and indicators used (STOCKING \& MURNAGHAN, 2001), indigenous perceptions are often indicative of what is happening on the ground (EGBE ET AL., 2014, RATSIMBAZAFY ET AL., 2012; APPIAH ET AL., 2009). The failed attempts at incorporating local views in degradation activities have often led to partial achievement of the set goals targeted at reducing degradation activities (STOCKING \& MURNAGHAN, 2001). In view of this, the corpus of studies posit that the recommendation and implementation of any degradation activity will not be able to yield its intended result without the critical input of indigenes (FISHER, 1995; LAWRENCE, 2000; HARES ET AL., 2006; BAATUUWIE ET AL., 2017). Few studies at the local level have examined the viewpoints and experiences of indigenes with regard to climate variability and change (EGBE ET AL., 2014; MACCHI ET AL., 2014; HAQUE ET AL., 2012; SÁNCHEZ-CORTÉS \& ChAVERo, 2011; LAMMEL ET AL., 2008; RINGROSE ET AL., 1996; HAGEBACK ET AL., 2005; KATZ ET AL., 1998; ORLOVE \& TOSTESON, 1999; ORLOVE ET AL., 2000, 2002; Conde ET AL., 2004; LEDUC, 2007; GREEN ET AL., 2010). 
Also mentioned in the research is the possible climatic impacts of land cover transformations, with particular emphasis on tropical deforestation (HENDERSON-SELLERS \& GORNITZ, 1984), climate change and forest disturbances (DALE ET AL., 2001), managing forests for climate change mitigation (CANADELL \& RAUPACH, 2008) and climate change, deforestation, and the fate of the Amazon (MALHI ET AL., 2008). These previous studies have only looked largely at the adverse impacts of forest cover degradation and climate variability and climate change. However, the bi-directional relationships have largely been ignored in the previous studies undertaken globally, and in Ghana specifically. The focus of this paper is to fill this gap, by assessing the perceived interaction between deforestation and/or forest degradation and climate variability and change (CVC) in the Ejisu-Juaben Municipality of the Ashanti Region of Ghana.

\subsection{Literature review}

The success of efforts targeted at combating climate change in developing countries lies in reducing carbon emissions from deforestation and/or forest degradation (GIBBS ET AL., 2007; BACCINI ET AL., 2012). The necessity to ensuring a reduction in deforestation is based on the premise that the second largest anthropogenic source of carbon dioxide to the atmosphere, after fossil fuel combustion is deforestation (VAN DER WERF ET al., 2009). A fifth of all global carbon emissions (UNFCCC, 2009), or between $10 \%$ and $15 \%$ of global carbon dioxide are by-products of deforestation and degradation of tropical forests (VAN DER WERF ET AL., 2009; IPCC, 2007).

The significant contribution of deforestation and/or forest degradation to climate change led to the UNFCC meeting in Montreal in 2005, by the Coalition for Rainforest Nations, on a proposed incentive for countries to control emissions by reducing deforestation. The proposal to curb carbon emissions evolved into the Reduced Emissions from Deforestation and Degradation (REDD). REDD depended on the mapping and monitoring of tropical forest carbon stocks and emissions over large geographic areas (ANGELSEN, 2008; UNFCC, 2009; ASNER ET AL., 2010). More importantly, the REDD program was a costeffective way to mitigate anthropogenic greenhouse gas emissions (GULLISON ET AL., 2007). This is because, the concept saw to the provision of financial incentives to help developing countries voluntarily reduce national deforestation rates and its associated carbon emissions below a baseline (based either on a historical reference case or future projection) (GIBBS ET AL., 2007).

Forests are an important natural 'brake' on climate change and do sequester and/or store more carbon than any other terrestrial ecosystem. However, when forests are cleared, or degraded, carbon stored above and below ground in leaves, branches, stems and roots is released to the atmosphere. Hence, deforestation, especially in the tropics, is estimated to release about 1 to 2 billion tonnes of $\mathrm{CO}_{2}$ per year, roughly $15-25 \%$ of annual global greenhouse gas emissions (MALHI \& GRACE, 2000). Though the proportion of carbon stored in forests comprises $70-80 \%$ of total terrestrial carbon (HOUGHTON, 2008), the spatial and temporal variability in carbon storage is substantial (ASNER ET AL., 2010). In Africa, about $70 \%$ of total carbon emissions are antecedents of deforestation and/or forest deforestation (FAO, 2005). Further, important carbon sinks are destroyed through deforestation thus hampering stabilization of current and future $\mathrm{CO}_{2}$ sequestration from the atmosphere (STEPHENS ET AL., 2007). It is estimated that Ghana lost 2.51 million hectares (or 33.70 per cent) of its forest cover between 1990 and 2010, representing a 2.03 per cent average annual loss over the period (NDPC, 2015).

Perceptions about climatic change can help fill gaps in scientific weather data and can be indispensable to researchers and policymakers (MACCHI ET AL., 2014). Perceptions are understood as an awareness and grasp of the environment by individuals and groups in the broader sense (WHYTE, $1977,1985)$ since perceptions influence the type of questions, explanations, meanings and values that we give to the world within which we live (LAZOS \& PARÉ, 2000). In Nigeria, rural people have been recognised as knowledge holders on climate variability/change and are key actors for developing mitigation and coping policies (EGBE ET AL., 2014). Protection of forest resources may not be successful when communities living within the vicinity of such resources are not considered in the formulation of policies with regard to the protection of resources (AGRAWAL \& GIBSON, 1999; FERRARO, 2002; OSTROM, 1999; Robertson \& Lawes, 2005; WIGGINS ET AL., 2004).

\section{Methodology}

\subsection{Study context}

The project area transcends across Ejisu, Tikrom, Krapa and Achiase, within the administrative boundaries of the Ejisu-Juaben Municipality within 
the Ashanti Region, Ghana. The study area is generally characterized by its moist semi equatorial climate and has long been noted for receiving double maxima rainfall (major season) observed between March - July $(1750 \mathrm{~mm})$ and a minor season in September - November (1200 mm) coupled with a mean annual temperature range of between $32^{\circ} \mathrm{C}$ and $20^{\circ} \mathrm{C}$ respectively. Moreover, the Municipality covers a land surface area of $582.5 \mathrm{~km}^{2}$ and shares a boundary with six other districts including the Sekyere East District at the north-eastern border, Kwabre East District at the north-western border and to the south are the Bosomtwe and Asante-Akim South District and to the east is Asante-Akim North Municipal and west is the Kumasi Metropolitan Assembly. Geographically, the Municipality is defined by Latitudes $1{ }^{0} 15^{\prime} \mathrm{N}$ and $1^{0} 45^{\prime} \mathrm{N}$ and Longitudes $6^{0} 15^{\prime} \mathrm{W}$ and $7^{\circ} 0^{\prime} \mathrm{W}$, and has a total population of 143,762 in 2010 of which males constitute 68,648 and females 75,114 respectively (GSS, 2014) (Fig. 1).

The vegetation type associated with the municipality is the moist semi deciduous forest which does not differ much in appearance from rainforest vegetation. Notable tree species within the study prefecture include: Triplochiton screloxylon, Terminalia superba, Nesogodonia papaverifera, Aningeria robusta, Chrysophyllum albidum, Pericopsis elata and Entandrophragma (twelve species of deciduous trees in the Mahogany family Meliaceae) (BUREAU OF INTEGRATED RURAL Development, 2001). However, the rapid land use and land cover clearance due to agricultural expansion (GEIST \& LAMBIN, 2001), population growth, urbanization and demand for forest resources have triggered forest reduction in the Ejisu-Juaben Municipality: forest in the Municipality has decreased from 20,385.04 ha in 1986 to $12,324.62$ ha in 2004 representing an annual rate of 0.65 percent (ASUBONTENG, 2007). This suggests that the municipality is undergoing forest transfers and implies the rate of climate change vulnerability in the region is high (ASUBONTENG, 2007). Other human induced activities such as ecologically unfriendly farming practices and illegal chain saw operations have resulted in the natural vegetation cover being degraded into secondary forest. The district was ideal for the study due to increased deforestation rate in the Municipality which was considered as critical hence, a recommendation by the Ghana Statistical Service that efforts should be put in place to reduce the felling of trees for firewood and charcoal, as well as implementing policies to reduce the use of firewood for cooking in the entire Municipality (GSS, 2014).

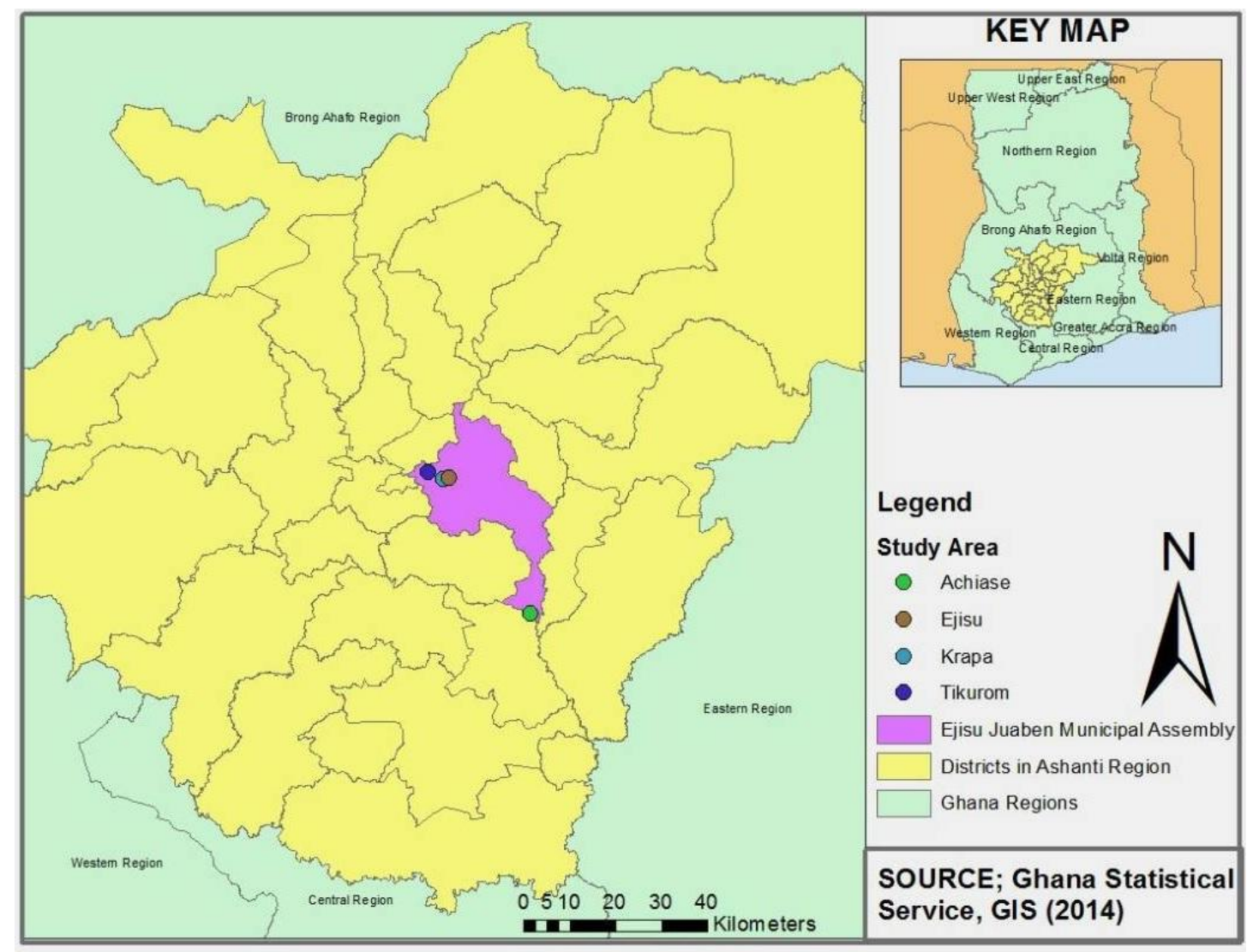

Fig. 1. Study Communities in the Ejisu-Juaben Municipality, Ghana 


\subsection{Sampling procedure and instrument of data collection}

Criterion, a type of purposive sampling, and simple random sampling techniques were employed for selecting the study district, communities and respondents. Criterion sampling involves the search for cases which meet a certain criteria (PALYS, 2008; BERNARD, 2002; ETIKAN ET AL. 2016). Thus, EjisuJuaben Municipality, and the four communities, were selected because they satisfy the criteria for a region where forest removal and deforestation activities are at an alarming rate, and described as critical (GSS, 2014). The four communities sampled for the study include Ejisu, Tikrom, Achiase and Krapa. The study participants were sampled using simple random sampling where each unit in the accessible population had an equal chance of being selected, and the chances of each unit was not affected by the selection of other units from the accessible population (TEDDLIE \& YU, 2007). This sampling technique ensured generalisability of the study findings (TASHAKKORI \& TEDDLIE, 2003a). In sum, the four communities had a household size of 5125. Applying the following parameters:

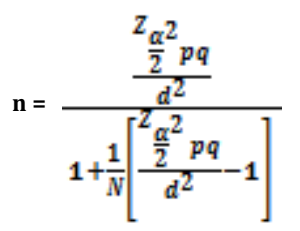

where:

$\mathrm{n}$ = sample size, $\mathrm{N}=$ population size (in this case $\mathrm{N}=$ 5125), $\mathrm{p}=$ estimated proportion of the population ( $\mathrm{p}$ $=0.5), q=(1-p)$ (i.e., $q=0.5), d=$ one half of the desired interval width $(\mathrm{d}=0.05)$, and $\mathrm{z}=$ the value of the standard normal distribution for the selected confidence level of $95 \%(z=1.96)$, a total sample size for the study was estimated at 360 (see Table 1).

The study adopted the empiricist paradigm (CRESWELL, 2003). The empiricist paradigm deals with the use of questionnaires in soliciting participants view on a research topic. Due to the diverse socio-economic background of the respondents, the questionnaire was designed in English but translated into the local dialect (Asante Twi) thus, serving the needs of both the formally and not-formally educated respondents. The instrument was designed to evaluate the demographic characteristics of the respondents, their perception about deforestation and forest degradation, the relationship between climate variability and change (CVC) and forest cover and the relationship between forest cover removal and climate variability (CVC). The questionnaires were administered to the participants in their homes, with each interaction spanning on average 30 minutes. The use of a questionnaire was deemed appropriate for the study because of its independence from researcher's bias, the replicability of study findings no matter who carries out similar studies and its depth in achieving breadth of understanding in the topic under research (PATTON, 2002). Perceptions about climate variability and change is complemented with a time-series analysis of annual rainfall, accumulated mean rainfall of Ejisu-Juaben Municipal (EJM) in (mm), rainfall trend in EJM from 19972012 and the temperature trend of EJM (19802012) from the Ejisu-Juaben Meteorological Service.

Table 1. Sample distribution over the surveyed villages

\begin{tabular}{|l|c|c|}
\hline \multicolumn{1}{|c|}{ Community } & $\begin{array}{c}\text { Population Size } \\
\text { (Households) }\end{array}$ & $\begin{array}{c}\text { Forest } \\
\text { Dependency }\end{array}$ \\
\hline Ejisu & $3191(\mathrm{n}=60)$ & Medium \\
\hline Tikrom & $523(\mathrm{n}=100)$ & Major \\
\hline Achiase & $711(\mathrm{n}=100)$ & Major \\
\hline Krapa & $700(\mathrm{n}=100)$ & Major \\
\hline Total & $5125(\mathrm{n}=360)$ & \\
\hline
\end{tabular}

Individuals with diverse socio-cultural, and socioeconomic backgrounds: both formal and informal sector, were sampled for the study. Both men and women who make use of forest resources made up the 360 respondents. The involvement of individuals with varying socio-economic backgrounds is premised on the fact that diverging opinions emanate from different interest groups even though they use the same environmental resource (STOCKING \& MURNAGHAN, 2001).

\subsection{Data management and analysis}

In order to ensure reliability and validity of the data, significant data cleaning (e.g., examination of data for outliers, normality and analysis of missing data) were performed by the authors after entry into the Predictive Analytics SoftWare (PASW) version 16. Moreover, assumptions needed to fulfill the use of some tools: particularly chisquare test and regression analysis, were assessed in order to ensure the validity of its result (VARDEMAN \& MORRIS, 2003). Descriptive statistics (mean and frequencies) and graphic displays were generated and presented for easy understanding and explanation of the phenomenon on the ground. Chi-square test analysis $\left(\chi^{2}\right)$ with a $5 \%$ level of significance was conducted to examine the relationship and/or significant difference between 
the study variables. Also, the binary logistic regression was conducted to explore the effect of other explanatory variables on the dependent variables which were not explained or captured by the chi-square test analysis. Whereas the data assumed its original measurement scale during the binary logistic regression analysis, all the data were assumed as equal (homogenous): with the same scale of measurement (nominal), before the chi-square test analysis was conducted.

\subsection{Ethical consideration}

Informed consent is paramount in research studies as its absence often hinders social scientists from interacting with participants during field work (ISRAEL \& HAY, 2006). In view of this, student ID cards were shown to the respondents as proof of the researchers' identity as students from the Department of Geography and Rural Development, KNUST.

The purpose of the study was explained to these respondents for their consent before participation (CLARKE, 1991, ARMIGER, 1997), protection of their dignity (FOUKA \& MANTZOROU, 2011) and the beneficence (FORD \& REUTTER, 1990; BEAUCHAMP \&
ChILDREs, 2001) of the study to the Municipality. Moreover, the study participants were briefly informed about the purpose of the study and were assured that their response would be handled with the utmost confidentiality and anonymity. Hence, no names were recorded during interaction with the respondents.

\section{Results}

\subsection{Demographic characteristics of respondents}

Table 2 presents the biodata of the respondents by gender. In sum, 360 participants, made up of $51 \%$ males and $49 \%$ females were involved in the study. The majority $(168,47 \%)$ of the respondents had attained a basic education, had a household size between 6-10 $(159,44 \%)$ and were in multiple households $(195,54 \%)$. Most of the participants were farmers (37\%) and had an average monthly income between GH\$ 51 - GH\$ $300(162,45 \%)$. Besides the educational level of the study participants, there were statistically significant differences between the male and female respondents $(p<0.05)$ from the Pearson Chi-square test conducted.

Table 2. Biodata of respondents

\begin{tabular}{|c|c|c|c|c|c|}
\hline \multirow{3}{*}{ Variables } & \multirow{3}{*}{ Responses } & \multicolumn{3}{|c|}{ Gender } & \multirow{3}{*}{$p$-value } \\
\hline & & Male & Female & Total & \\
\hline & & $\mathrm{N}(\%)$ & $\mathrm{N}(\%)$ & $\mathrm{N}(\%)$ & \\
\hline \multirow[t]{4}{*}{ Educational level } & No formal education & $30(16.4)$ & $42(23.7)$ & $72(20)$ & 0.305 \\
\hline & Basic & $87(47.5)$ & $81(45.8)$ & $168(46.6)$ & \\
\hline & SHS/TEC/VOC & $33(18)$ & $21(11.9)$ & $54(15)$ & \\
\hline & Tertiary & $33(18)$ & $33(18.6)$ & $66(18.3)$ & \\
\hline \multirow[t]{5}{*}{ Household size } & $1-5$ & $48(26.2)$ & $54(30.5)$ & $102(28.3)$ & $0.008^{*}$ \\
\hline & $6-10$ & $72(39.3)$ & $87(49.1)$ & $159(44.2)$ & \\
\hline & $11-15$ & $33(18)$ & $24(13.6)$ & $57(15.8)$ & \\
\hline & $16-20$ & $6(3.3)$ & $6(3.4)$ & $12(3.3)$ & \\
\hline & $20+$ & $24(13.1)$ & $6(3.4)$ & $30(8.3)$ & \\
\hline \multirow[t]{2}{*}{ Type of household } & Single household & $66(36.1)$ & $99(55.9)$ & $165(45.8)$ & $0.000^{*}$ \\
\hline & Multiple household & $117(63.9)$ & $78(44.1)$ & $195(54.2)$ & \\
\hline \multirow[t]{6}{*}{ Occupation } & Farming & $87(47.5)$ & $84(47.4)$ & $171(47.5)$ & \\
\hline & Teaching & $15(8.2)$ & $18(10.2)$ & $33(9.2)$ & \\
\hline & Artisanship & $39(21.3)$ & $12(6.8)$ & $51(14.2)$ & $0.000^{*}$ \\
\hline & Herbal medicine production & $3(1.6)$ & $0(0)$ & $3(0.8)$ & \\
\hline & Trading & $39(21.3)$ & $51(28.8)$ & $90(25)$ & \\
\hline & Food vending & $0(0)$ & $12(6.8)$ & $12(3.3)$ & \\
\hline \multirow[t]{5}{*}{ Monthly income } & $\leq \mathrm{GH} \pitchfork 50$ & $12(6.6)$ & $36(203)$ & $48(13.3)$ & $0.002^{*}$ \\
\hline & GHథ 51 - GHథ 300 & $87(47.5)$ & $75(42.4)$ & $162(45)$ & \\
\hline & GHф $301-$ GHф 500 & $27(14.7)$ & $27(15.2)$ & $54(15)$ & \\
\hline & $\mathrm{GH} \$ 501-\mathrm{GH} \$ 900$ & $27(14.7)$ & $15(8.5)$ & $42(11.7)$ & \\
\hline & $\geq \mathrm{GH} \$ 901$ & $30(16.4)$ & $24(13.6)$ & $54(15)$ & \\
\hline
\end{tabular}

*statistically significant at $\mathrm{p}<0.05$ 
3.2. Climate variability and change scenarios for the municipality

Figure 2 shows the accumulated mean rainfall $(\mathrm{mm})$, the rainfall trend and temperature trend of Ejisu- Juaben Municipality (EJM). Fig 2a shows the accumulated mean rainfall whereas (Fig. 2b) depicts the rainfall trend. The rainfall trend (Fig. 2b) shows a steady decline in the total amount of rainfall in the study area from 1997 to 2012. From the diagram, it can be hypothesised that, the amount of rainfall in the Municipality will continue

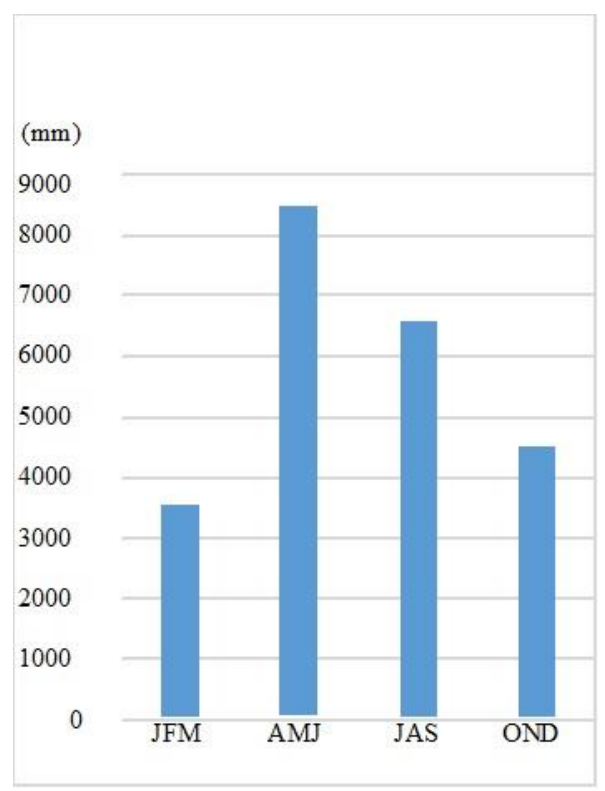

(a) to decrease. Although the Sen's estimate (Fig. 2c) found the decrease in rainfall to be insignificant, the increase in temperature by $10 \%$ within the range of rainfall decrease presents a troubling situation. This is evident in the slope of the rainfall distribution observed over the period. It can be observed from Fig. 2c that, temperature increased gradually from 1980 to 2012 at a rate of $10 \%$. It can be inferred from the preceding arguments that, temperature will continue to increase above Sen's estimate of $10 \%$, should deforestation persist.

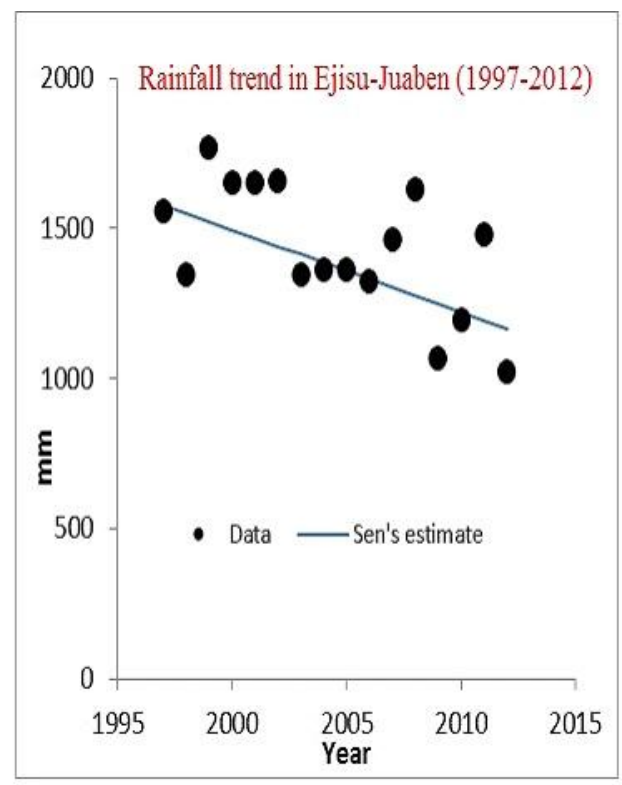

(b)

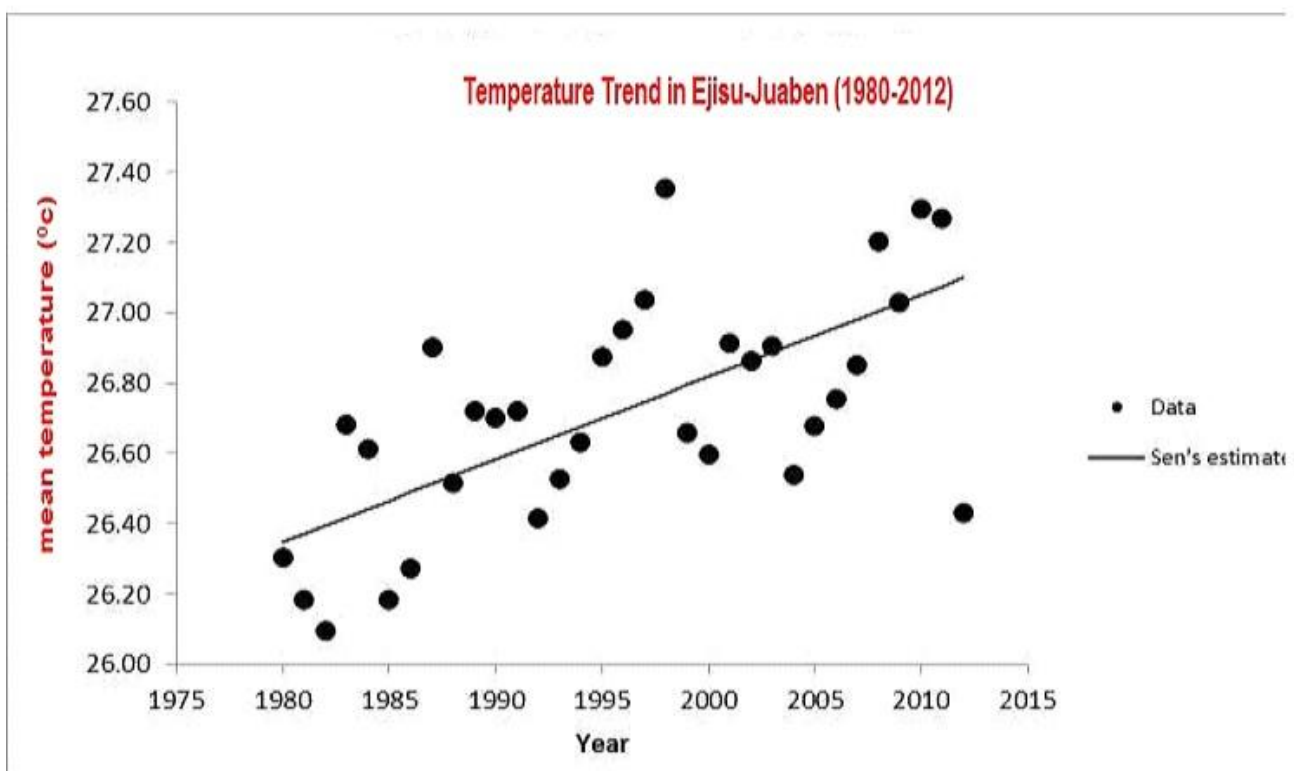

(c)

Fig. 2. Accumulated mean rainfall of Ejisu-Juaben Municipality (EJM) in mm (a); Rainfall trend in EJM from 1997-2012 (b); Temperature trend of EJM (1980-2012) (c)

JFM= January, February, March AMJ= April, May, June JAS= July, August, September OND=October, November, December 
3.3. Perception about climate variability and change (CVC)

The following indicators were used to examine participants' perceptions about CVC: changes in rainfall, changes in temperature and drought. All three indicators were perceived as antecedents of CVC by the respondents $(223,62 \%)$. The responses were significant $(\mathrm{p}<0.05)$ at the Pearson Chi-square test conducted (Table 3).

Table 3. Chi-Square test of Occupation by Perception about CVC

\begin{tabular}{|c|c|c|c|c|c|c|c|c|}
\hline \multirow{3}{*}{$\begin{array}{l}\text { Perception about } \\
\text { CVC }\end{array}$} & \multicolumn{6}{|c|}{ Occupation } & \multirow{2}{*}{ Total } & \multirow{3}{*}{$p$-value } \\
\hline & Farming & Teaching & Artisanship & $\begin{array}{c}\text { Herbal } \\
\text { medicine } \\
\text { production }\end{array}$ & Trading & $\begin{array}{c}\text { Food } \\
\text { vending }\end{array}$ & & \\
\hline & $\mathrm{N}(\%)$ & $\mathrm{N}(\%)$ & $\mathrm{N}(\%)$ & $\mathrm{N}(\%)$ & N (\%) & $\mathrm{N}(\%)$ & $\mathrm{N}(\%)$ & \\
\hline $\begin{array}{l}\text { Changes in } \\
\text { rainfall patterns }\end{array}$ & $36(21)$ & 4 (12.1) & $18(35.3)$ & $0(0)$ & $21(23.3)$ & $3(25)$ & 82 (22.8) & \\
\hline $\begin{array}{l}\text { Changes in } \\
\text { temperature }\end{array}$ & $18(10.5)$ & $2(6.1)$ & $6(11.8)$ & $0(0)$ & $8(8.9)$ & $0(0)$ & $34(9.4)$ & $0.000^{*}$ \\
\hline Drought & $11(6.4)$ & $3(9.1)$ & $0(0)$ & $3(100)$ & $4(4.4)$ & $0(0)$ & $21(5.8)$ & \\
\hline All the above & $106(62)$ & $24(72.7)$ & 27 (52.9) & $0(0)$ & $57(63.3)$ & $9(75)$ & 223 (61.9) & \\
\hline
\end{tabular}

*statistically significant at $\mathrm{p}<0.05$

\subsection{Relationship between climate variability and} change (CVC) and forest cover removal

As regards the relationship between CVC and forest cover removal, the majority $(45 \%)$ of the respondents considered that decreasing amounts of rainfall result in a continual reduction in their crop output. Such occurrences make their farming activities non-lucrative and also influence their decision to remove the forest cover for other purposes. Additionally, increasing temperature (31\%) influences respondents' decision to convert forest lands to other land use patterns (Fig. 3).

Similarly, in a binary logistic regression analysis in which "does CVC influence decisions to remove forest cover" was the dependent variable, respondents' with basic education [OR 2.802 (95\% CI 1.551-5.064), $\mathrm{p}=0.001]$ and in the SHS/TEC/VOC graduates [OR 3.036 (95\% CI 1.4506.357), $\mathrm{p}=0.003$ ] were more likely than those without any formal education to predict that CVC factors influence their decision to remove the forest. Respondents with multiple households [OR 0.488 (95\% CI 0.320-0.744), $\mathrm{p}=0.001$ ] had lower odds of predicting that CVC influences decisions to remove forest than those in single households. Consequently, teachers [OR 0.381 (95\% CI 0.149 0.973), $\mathrm{p}=0.044$ ], traders [OR 2.961 (95\% CI 1.7445.028), $\mathrm{p}=0.000$ ] and food vendors [OR 5.143 (95\% CI 1.342-19.701), $\mathrm{p}=0.017$ ] had greater odds of predicting that CVC factors influences decisions to remove forest (Table 4).

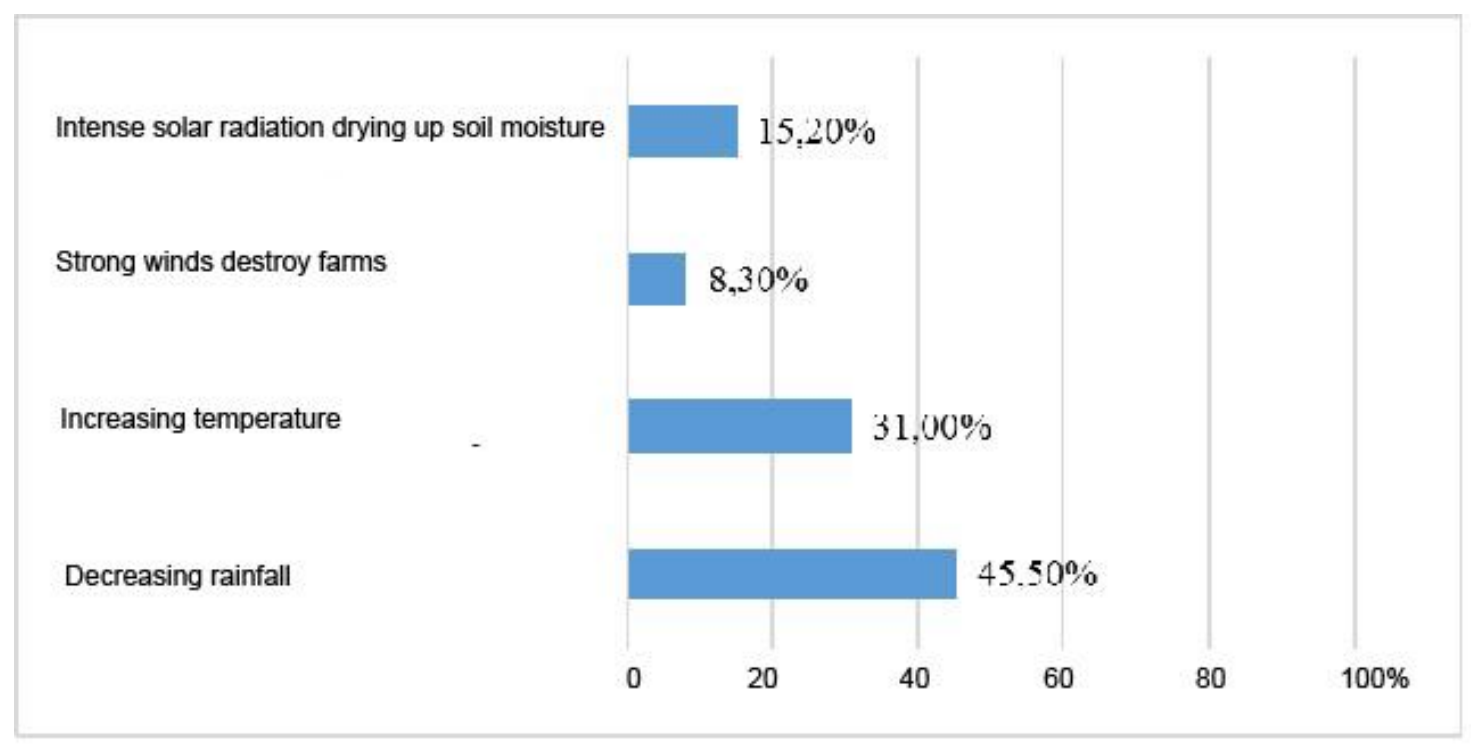

Fig. 3. Respondents' view on climate variability and change factors influencing decisions to remove forest cover 
Table 4. Predictors of the impact of CVC on forest cover removal

\begin{tabular}{|c|c|c|c|c|}
\hline \multirow[t]{2}{*}{ Covariate } & \multicolumn{3}{|c|}{$\begin{array}{l}\text { Does climate variability and change influence decisions to } \\
\text { remove forest cover }\end{array}$} & \multirow[t]{2}{*}{$p$-value } \\
\hline & $\beta$ & OR & $95.0 \%$ C.I & \\
\hline \multicolumn{5}{|l|}{ EDUCATION } \\
\hline No formal education & & 1 & & \\
\hline Basic education & 1.030 & 2.802 & $1.551-5.064$ & $0.001^{*}$ \\
\hline SHS/TEC/VOC & 1.110 & 3.036 & $1.450-6.357$ & $0.003^{*}$ \\
\hline Tertiary & 0.125 & 1.133 & $0.549-2.342$ & 0.735 \\
\hline \multicolumn{5}{|l|}{ TYPE OF HOUSEHOLD } \\
\hline Single household & & 1 & & \\
\hline Multiple household & -0.718 & 0.488 & $0.320-0.744$ & $0.001^{*}$ \\
\hline \multicolumn{5}{|l|}{ OCCUPATION } \\
\hline Farming & & 1 & & \\
\hline Teaching & -0.965 & 0.381 & $0.149-0.973$ & $0.044^{*}$ \\
\hline Artisanship & 0.421 & 1.524 & $0.810-2.866$ & 0.191 \\
\hline Herbal medicine production & 21.742 & 2.769 & 0.000 & 0.999 \\
\hline Trading & 1.086 & 2.961 & $1.744-5.028$ & $0.000^{*}$ \\
\hline Food vending & 1.638 & 5.143 & $1.342-19.701$ & $0.017^{*}$ \\
\hline
\end{tabular}

OR - odds ratio, CI - confidence interval,* ${ }^{*}$-statistically significant at p _ 0.05

\subsection{Perception about deforestation and forest degradation}

Due to the agrarian orientation of the study communities, a Chi-square test was used to test the relationship between respondents' occupation types and their perception about deforestation. Across the various occupation types, loss of forest cover was perceived as an indication of deforestation (yes $=67$, no $=11 \%, \mathrm{p}=0.000)$ compared to extinction of tree species (yes $=12 \%$, no $=87 \%$, $\mathrm{p}=0.005$ ) and changing forest to savanna (yes = $6 \%$, no $=94 \%, p=0.003$ ). Generally, there was a statistically significant difference across the occupation types. However, farmers' (132, 77\%) mostly perceived loss of forest cover as an indication of deforestation (Table 5).

Table 5. Chi-Square test of occupation by perception about deforestation

\begin{tabular}{|c|c|c|c|c|c|c|c|c|c|}
\hline \multirow{3}{*}{$\begin{array}{c}\text { Perception } \\
\text { about } \\
\text { deforestation }\end{array}$} & \multirow{3}{*}{$\begin{array}{l}\text { Yes/ } \\
\text { No }\end{array}$} & \multicolumn{6}{|c|}{ Occupation } & \multirow{2}{*}{ Total } & \multirow{3}{*}{$\begin{array}{c}p \text { - } \\
\text { value }\end{array}$} \\
\hline & & Farming & Teaching & Artisanship & $\begin{array}{c}\text { Herbal } \\
\text { medicine } \\
\text { production }\end{array}$ & Trading & $\begin{array}{c}\text { Food } \\
\text { vending }\end{array}$ & & \\
\hline & & $\mathrm{N}(\%)$ & $\mathrm{N}(\%)$ & $\mathrm{N}(\%)$ & $\mathrm{N}(\%)$ & $\mathrm{N}(\%)$ & $\mathrm{N}(\%)$ & $\mathrm{N}(\%)$ & \\
\hline \multirow{2}{*}{$\begin{array}{l}\text { Loss of forest } \\
\text { cover }\end{array}$} & Yes & $132(77.2)$ & 24 (72.7) & $33(64.7)$ & $3(100)$ & $45(50)$ & $6(50)$ & $243(67.5)$ & $0.000^{*}$ \\
\hline & No & $39(22.8)$ & $9(27.3)$ & $18(35.3)$ & $0(0)$ & $45(50)$ & $6(50)$ & $117(32.5)$ & \\
\hline \multirow[t]{2}{*}{ Felling of tree } & Yes & 84 (49.1) & $15(45.4)$ & $18(35.3)$ & $0(0)$ & $36(40)$ & $3(25)$ & $156(43.3)$ & 0.152 \\
\hline & No & 87 (50.9) & $18(54.5)$ & $33(64.7)$ & $3(100)$ & $54(60)$ & $9(75)$ & $204(56.7)$ & \\
\hline \multirow{2}{*}{$\begin{array}{l}\text { Extinction of } \\
\text { tree species }\end{array}$} & Yes & $12(7)$ & $3(9.1)$ & $6(11.8)$ & $0(0)$ & $21(23.3)$ & $3(25)$ & $45(12.5)$ & $0.005^{*}$ \\
\hline & No & 159 (93) & 30 (90.9) & $45(88.2)$ & $3(100)$ & 69 (76.7) & $9(75)$ & $315(87.5)$ & \\
\hline \multirow{2}{*}{$\begin{array}{l}\text { Changing } \\
\text { forest to } \\
\text { savanna }\end{array}$} & Yes & $6(3.5)$ & $6(18.2)$ & $0(0)$ & $0(0)$ & $9(10)$ & $0(0)$ & $21(5.8)$ & 0.003*, \\
\hline & No & $165(96.5)$ & 27 (81.8) & $51(100)$ & $3(100)$ & $81(90)$ & $12(100)$ & $339(94.2)$ & \\
\hline
\end{tabular}

*statistically significant at $\mathrm{p}<0.05$, percentages in parentheses 


\subsection{Relationship between forest cover removal and CVC}

Table 6 presents a chi-square test analysis on whether forest cover removal affects climate variability and change. Overall, $81 \%$ of the respondents posited that forest cover removal affects climate variability and change. Respondents with a formal education (basic education/ SHS/TEC/ VOC/tertiary, 80\%) and in the farming profession (47\%) perceived the removal of forest cover as a contributor to climate variability and change. Moreover, participants perceived the rates of vegetation cover change (about 1 ha/year +/-/ about $3 \mathrm{ha} /$ year+/-, 60\%) and rate of forest cover removal (very high, 57\%) as drivers of climate variability and change. These discoveries showed statistically significant differences among the various demographic characteristics and deforestation and forest degradation rate $(\mathrm{p}<0.05)$ from the Pearson's Chi-square analysis conducted.

Table 6. Perceived forest cover removal effect on CVC by demographic characteristics and deforestation and forest degradation rate

\begin{tabular}{|c|c|c|c|c|}
\hline \multirow[t]{3}{*}{ Covariate } & \multicolumn{2}{|c|}{$\begin{array}{l}\text { Does this forest cover removal affect } \\
\text { climate variability and change }\end{array}$} & \multirow[t]{2}{*}{ Total } & \multirow{3}{*}{$p$-value } \\
\hline & Yes & No & & \\
\hline & $\mathrm{N}(\%)$ & N (\%) & $\mathrm{N}(\%)$ & \\
\hline \multicolumn{5}{|l|}{ EDUCATION } \\
\hline No formal education & $66(22.7)$ & $6(8.7)$ & $72(20)$ & $0.000^{*}$ \\
\hline Basic & $117(40.2)$ & $51(73.9)$ & $168(46.7)$ & \\
\hline SHS/TEC/VOC & $45(15.5)$ & $9(13.0)$ & $54(15)$ & \\
\hline Tertiary & $63(21.6)$ & $3(4.3)$ & $66(18.3)$ & \\
\hline \multicolumn{5}{|l|}{ OCCUPATION } \\
\hline Farming & $144(49.5)$ & $27(39.1)$ & $171(47.5)$ & $0.001^{*}$ \\
\hline Teaching & $33(11.3)$ & $0(0)$ & $33(9.2)$ & \\
\hline Artisanship & $33(11.3)$ & $18(26.1)$ & $51(14.2)$ & \\
\hline Herbal medicine production & $3(1.0)$ & $0(0)$ & $3(0.8)$ & \\
\hline Trading & $69(23.7)$ & $21(30.4)$ & $90(25.0)$ & \\
\hline Food vending & $9(3.1)$ & $3(4.3)$ & $12(3.3)$ & \\
\hline \multicolumn{5}{|c|}{ RATES OF VEGETATION COVER CHANGE } \\
\hline About 1 ha/year+/- & $79(27.1)$ & $31(44.9)$ & $110(30.6)$ & $0.005^{*}$ \\
\hline About 2 ha/year+/- & $60(20.6)$ & $12(17.4)$ & $72(20.0)$ & \\
\hline About 3 ha/year+/- & $96(33.0)$ & $10(14.5)$ & $106(29.4)$ & \\
\hline About 4 ha/year+/- & $56(19.2)$ & $16(23.2)$ & $72(20.0)$ & \\
\hline \multicolumn{5}{|l|}{ RATE OF FOREST COVER REMOVAL } \\
\hline Very high & $168(57.7)$ & $39(56.5)$ & $207(57.5)$ & $0.042^{*}$ \\
\hline High & $72(24.7)$ & $13(18.8)$ & $85(23.6)$ & \\
\hline Low & $45(15.5)$ & $11(15.9)$ & $56(15.6)$ & \\
\hline Very low & $6(2.1)$ & $6(8.7)$ & $12(3.3)$ & \\
\hline
\end{tabular}

*statistically significant at $\mathrm{p}<0.05$, percentages in parentheses

It is important to indicate that using the Chisquare test does not allow for the potential influence of other explanatory variables on the relationship presented in Table 6. The Chi-square tests concluded that there was evidence of a relationship between "forest cover removal effect on CVC" by demographic characteristics and deforestation and forest degradation rate. In order to ascertain the potential influence of other explanatory variables, a binary logistic regression analysis was conducted with the predictive variables unadjusted. The result indicates that respondents with basic education [OR 4.795 (95\% CI 1.952-11.771), $\mathrm{p}=0.001]$, were 4 times more likely to predict that forest cover removal leads to climate variability and change than those with no formal education. Quite surprisingly, as regards respondents' occupation, artisans had greater odds of predicting that forest cover removal leads to climate variability and change than 
With respect to deforestation and forest degradation rate, changing vegetation cover at a rate of about 3 ha/year+/- [OR 0.265 (95\% CI 0.123-0.575), $\mathrm{p}=0.001]$ and removing forest cover at a lower rate [OR 4.308 (95\% CI 1.318-14.075), $\mathrm{p}=0.016$ ] were likely to affect CVC (Table 7).

Table 7. Predictors of impact of forest cover removal on climate variability and change

\begin{tabular}{|c|c|c|c|c|}
\hline \multirow{2}{*}{ Covariate } & \multicolumn{3}{|c|}{ Does this forest cover removal affect climate variability and change } & \multirow{2}{*}{$p$-value } \\
\hline & $\beta$ & OR & $95.0 \%$ C.I & \\
\hline \multicolumn{5}{|l|}{ EDUCATION } \\
\hline No formal education & & 1 & & \\
\hline Basic education & 1.568 & 4.795 & $1.953-11.771$ & $0.001^{*}$ \\
\hline SHS/TEC/VOC & 0.788 & 2.200 & $0.732-6.611$ & 0.160 \\
\hline Tertiary & -0.647 & 0.524 & $0.126-2.185$ & 0.375 \\
\hline \multicolumn{5}{|l|}{ OCCUPATION } \\
\hline Farming & & 1 & & \\
\hline Teaching & -19.529 & 0.000 & 0.000 & 0.998 \\
\hline Artisanship & 1.068 & 2.909 & $1.436-5.895$ & $0.003^{*}$ \\
\hline Herbal medicine production & -19.529 & 0.000 & 0.000 & 0.999 \\
\hline Trading & 0.484 & 1.623 & $0.857-3.073$ & 0.137 \\
\hline Food vending & 0.575 & 1.778 & $0.452-6.995$ & 0.410 \\
\hline \multicolumn{5}{|c|}{ RATES OF VEGETATION COVER CHANGE } \\
\hline About 1 ha/year+/- & & 1 & & \\
\hline About 2 ha/year+/- & -0.674 & 0.510 & $0.242-1.705$ & 0.077 \\
\hline About 3 ha/year+/- & -1.326 & 0.265 & $0.123-0.575$ & $0.001^{*}$ \\
\hline About 4 ha/year+/- & -0.317 & 0.728 & $0.364-1.457$ & 0.370 \\
\hline \multicolumn{5}{|l|}{ RATE OF FOREST COVER REMOVAL } \\
\hline Very high & & 1 & & \\
\hline High & -0.251 & 0.778 & $0.392-1.544$ & 0.473 \\
\hline Low & 0.052 & 1.053 & $0.500-2.219$ & 0.892 \\
\hline Very low & 1.460 & 4.308 & $1.318-14.075$ & $0.016^{*}$ \\
\hline
\end{tabular}

OR - odds ratio, CI - confidence interval, ${ }^{*}$-statistically significant at $\mathrm{p}<0.05$

\section{Discussion}

Perceptual studies on the environment-natural resources nexus are important if the malpractices and unsustainable use of these resources are to be abated. This study has assessed the synergistic relationship between deforestation and/or forest degradation and climate variability and change [CVC], based on participants self-report in the EjisuJuaben Municipality. Being an agrarian community, agriculture remains the main economic activity in the Municipality though other mix of economic activities exist (GSS, 2014). Meanwhile, the majority of the study participants variously depend on the forest for their livelihood activities and income (WORLD BANK, 2000; SCHERL ET AL., 2004; USAID, 2006; ANDERSON ET AL., 2006). Our study findings report that farming is the economic activity mostly affected by changes in climate: CVC made farming activities non-lucrative through decreased amount of rainfall and increasing temperature (WoRLD BANK, 2017; MACCHI ET AL., 2014; SÁNCHEZCoRTÉs \& CHAVERO, 2011; CHAUdHARY \& BAWA, 2011; OWUSU ET AL., 2008; LOBELL \& FIELD, 2007; UNDP, 2007). This problem confirms earlier reports that, as a world-wide problem, CVC represents a significant threat and challenge to peoples' livelihoods (WORLD BANK, 2017; IPCC, 2014; OLSSON ET AL., 2014; FAO, 2009; Athula \& SCARbOROUGh, 2011; Codjoe \& OWUSU, 2011; DAMPTEY \& MENSAH, 2008; NELSON \& AGBEY, 2005), and also changes, or disrupts, livelihood patterns among community members from agriculture to non-agricultural activities (MACCHI \& ICIMOD TEAM, 2010; LAMMEL ET AL., 2008; STIGTER ET AL., 2005; RSAS, 2002). However, in these studies, the negative effect of CVC on 
respondents' livelihood activities did not lead to the destruction of forest resources.

Due to the close association of the majority's occupation, farming, to their immediate environment, the distortion of their livelihood activity led to the depletion, or removal, of the forest to other land uses. This assertion was supported by those whose primary occupation was not farming. This confirms earlier studies where changes in climatic variables were destroyers of natural resources, specifically, the forest ecosystem (IPCC, 2007; LOCATELLI ET AL., 2008; SEPPÄLÄ ET AL., 2009). Quite surprisingly, the poor economic condition of the respondents due to low crop output was not the underlying reason for the increasing deforestation activities in the Municipality (PEPRAH ET AL., 2017). Rather, CVC was reported as the underlying factor influencing respondents' decision to clear the forest for other economic purposes as a means to ensuring their livelihood sustainability.

In studies such as ARIZPE ET AL. (1993) and SÁNCHEZ-CORTÉS \& CHAVERO (2011), where gender and geographical location were the predictors of CVC, respondents' education and occupation were the predictors of CVC in the present study. Generally, respondents with different socioeconomic background aptly perceived that CVC influences one's decision to remove, or clear, the forest for other purposes. Contrary to the popular notion that farming activities, timber extraction, fuelwood and charcoal collection, forest fires, settlement purposes, conflict (MORARA ET AL., 2014; HOSONUMA ET AL., 2012; KIOKO ET AL., 2012; KIOKO \& OKELlo, 2010; BlaY ET AL., 2007; KLOOSTER, 2003; APPIAH, 2001; APPIAH ET AL., 2009; WAGNER \& COBBINAH, 1993) and the complex interactions of underlying social, political, economic, technological and cultural forces (GEIST \& LAMBIN, 2001) drives deforestation and/or forest degradation, our study findings report that CVC influences respondents' decision to destroy forest resources. Further contradiction is evident from the statistical report about the Municipality where an increase in demand for fuel wood and agricultural lands due to population growth in rural areas was the driving factor of deforestation activities (GSS, 2014).

It is noteworthy to indicate that, though respondents were not familiar with the term "climate variability and change", based on their indigenous knowledge, they perceived the decline in rainfall amount and high temperature as indicators of changes in the weather pattern and its consequential impacts on climate. Their perception about the changes in rainfall patterns and temperature, however, is in agreement with that of the Municipality's and other recognisable organisations definitions and understandings of climate change and variability. This indicates that respondents are better informed about changes in climate variability in their locality though their local knowledge and experiences are not scientifically motivated (SÁNCHEZ-CORTÉS \& Chavero, 2011). Thomas ET AL. (2007) state that the "variations in the means of climate variables are not sufficient to identify attributes of climate impact observed and experienced by local inhabitants, as it is only they that have a day to day relationship with the weather and climate and can distinguish continuities or variants as regards the local climate, something which is not visible in statistics". With this, participants who were having constant interaction with the elements of climate, especially rainfall and temperature in their day to day economic activities and other non-economic activities through their experiences may have perceptions that reflect the actual climate change and variability scenarios.

According to HosonUma ET AL. (2012, pp. 1) "understanding drivers of deforestation and degradation is fundamental for the development of policies and measures that aim to alter current trends in forest activities toward a more climate and biodiversity...friendly outcome". The loss of forest cover, felling trees, extinction of tree species and changing hitherto forested lands to savanna were perceived as indicators of deforestation. Narrowing down to the synergy between deforestation and CVC, respondents across the various educational spectrum (both formally educated and formally uneducated) and occupation types, perceived CVC as an antecedent of forest cover removal. Inferences from the participants perception, brings to light their inherent knowledge on the changing climatic elements in the Municipality as regards rainfall and temperature patterns, due to the continual conversion, and removal of forested lands into other land uses. This is in support of studies by CHENG \& CHAN (2012) who reported that converting forest resources into other land uses affects climate through changes of the near surface energy and moisture exchange, by changing the atmospheric concentrations of greenhouse gases. Forest cover removal releases carbon stored above and below the ground in leaves, branches, stems and roots into the atmosphere thus, increasing the concentration of atmospheric $\mathrm{CO}_{2}$ (MALHI \& GRACE, 2000; HOUGHTON, 2005). Other studies have variously reported that forest degradation and/or deforestation impact negatively on climate (CARVALHO ET AL., 2017; 
IPEA, 2011; COP 151, UNFCCC, 2009, 2010; BENDORF ET AL., 2007). Thus, in an attempt to remediate climate change, the need to protect the remaining forest from further degradation has been suggested (CARVALHO ET AL., 2017; SÁNCHEZCORTÉs \& CHAVERo, 2011; RATSIMBAZAFY ET AL., 2012; FERGUSSON, 2009).

The forgone discussion succinctly reveals the close association between the forest ecosystem \& CVC. The NASA Earth Observatory report ${ }^{2}$ indicates that, "though deforestation meets some human needs, it also has profound, sometimes devastating, consequences, including...climate change". Moreover, Tinker \& colleagues reported in their study that, "the net $\mathrm{CO}_{2}$ balance in shifting cultivation is near zero if the forest returns to its original biomass \& soil organic carbon status, although there is a small net release of other greenhouse gases during the cropping cycle. Deforestation by contrast normally causes large losses of $\mathrm{CO}_{2}$ from the soil and vegetation (TINKER ET AL., 1996).

With regard to respondents' demographic characteristics, besides the educational level of participants, the study discovered a statistically significant difference between the male and female respondents $(p<0.05)$. Males were more likely to have multiple households, be either farmers and/or artisans and have huge average monthly incomes than the females. Our findings draw attention to other drivers of deforestation and forest degradation in the Municipality in particular, and the country in general, which deviate sharply from the known causes identified in previous studies. The major strength of this study is that it remains the first population-based study to offer elucidation, regarding the synergistic association between forest degradation or deforestation and climate variability and change in Ghana and the Ejisu-Juaben Municipality. However, the study is beset with some limitations. Though the study examined indigenous perception about the association between deforestation and/or forest degradation and climate variability and change in the Ejisu-Juaben Municipality, it was limited to only four communities. Tackling this drawback was the fact that a representative sample and randomization procedures were

\footnotetext{
15 COP15 (United Nations Conference on Climate Change), held from December 7-18, 2009, in Copenhagen brought together 193 member countries of the United Nations Framework Convention on Climate Change. Its proposal was to define a global action agenda to control global warming and ensure the survival of the human species

2 ttps://earthobservatory.nasa.gov/Features/Deforestation/ deforestation_update.php
}

followed in the generation of the study results. However, replication of this research and followup studies in other communities within the Municipality, as well as other Municipalities in the country, would be useful to confirm the consistency of the findings of the current research.

\section{Conclusion}

This study highlights the synergetic relationship between deforestation and/or forest degradation and climate variability and change based on indigenous self-report. The study found empirical evidence to suggest that climate variability influences respondents' decision to convert forest resources, whereas deforestation and/or forest degradation negatively impacts climate. Generally, participants across the various socioeconomic statuses were adequately informed, and knowledgeable about changes in climatic variables based on their observations. Specifically, participants perceived the changes in rainfall patterns, accompanied by increasing temperature and drought, as indicators of CVC, whose impact are significant enough to influence their decision to convert forest resources into other land uses for livelihood sustainability purposes. Consequently, participants perceived the loss of forest, extinction of tree species and changing forest to savanna lands as indications of deforestation with negative implication on climate. Our study findings buttress the fact that knowledge of local perceptions are fundamental for gaining in-depth and better understanding of the impacts of climate change on forest resources which may stretch back for decades (BYG \& SALICK, 2009; CHAUDHARY \& BAWA, 2011; Chaudhary ET AL., 2011; VEDWAN \& RHOADES, 2001). In Ghana, most rural communities live very close to the forest and are major and direct consumers of the goods and services from the forest. Hence, excluding their opinions and knowledge on issues regarding the protection of such resources makes them lose their self-image as trustees of the forest resources and could further jeopardise the success of the policies. In light of this, the study recommends that policies targeted at reducing forest degradation, or deforestation, and contributing to the fight against climate variability and change in the Municipality should henceforth take into consideration the opinions of the indigenes in addition to scientific evidence in order to make such policies effective. 


\section{Acknowledgement}

The authors acknowledges the time and participation of indigenes in the Ejisu-Juaben Municipality for providing the responses which formed the basis of our study findings.

\section{References}

Abbiw D. 1990. Useful plants of Ghana: West African uses of wild and cultivated plants. Intermediate Tech. Publ., London.

Agrawal A., Gibson C. 1999. Enchantment and disenchantment: The role of community in natural resource conservation. World Dev., 27(4): 629-649.

Alston L.J., Libecap G.C., Muller B. 2000. Land reform policies, the sources of violent conflict, and implications for deforestation in the Brazilian Amazon. J. Environ. Econ Manag. 39: 162-188. http://dx.doi.org/10.1006/jeem. 1999.1103.

Anderson J., Benjamin C., Campell B., Tiveau D. 2006. Forests, poverty and equity in Africa: new perspectives on policy and practice. Int. For. Rev., 8(1): 44-53.

Andreae M.O., Rosenfeld D., Artaxo P., Costa A.A., Frank G.P., Longo K.M., Silva-Dias M.A. 2004. Smoking rain clouds over the Amazon. Science, 303(5662): 1337-42.

Angelsen A. 2008. Moving Ahead with REDD: Issues, Options and Implications. Center for International Forestry Research, Bogor, Indonesia.

Appiah M. 2001. Co-partnership in forest management: The Gwira-Banso joint forest management project in Ghana. Environ. Dev. Sustain., 3(4): 343-360.

Appiah M., Blay D., Damnyag L., Dwomoh F.K., Pappinen A., Luukkanen 0. 2009. Dependence on forest resources and tropical deforestation in Ghana. Environ. Dev. Sustain., 11: 471-487. DOI: 10.1007/s10668-007-9125-0.

Arizpe L., Paz F. Velásquez M. 1993. Cultura y cambio global: percepciones sociales sobre la deforestación en la Selva Lacandona. Centro Regional de Investigaciones Multi disciplinarias-Universidad Nacional Autónoma de México/ Porrúa, México

Armiger B. 1997. Ethics in Nursing Research: Profile, Principles, Perspective. Nursing Research, 26 (5): 330-333.

Asner G.P., Powell G.V.N., Mascaro J., Knapp D.E., Clark J.K., Jacobson J., Kennedy-Bowdoin T., Balaji A., Paez Acosta G., Victoria E., Secada L., Valqui M., Hughes R.F. 2010. High-resolution forest carbon stocks and emissions in the Amazon. Proc. Natl. Acad. Sci. USA, 107(38). DOI:/10.1073/pnas.1004875107.

Asubonteng K. 2007. Identification of land use/cover transfer hotspots in the Ejisu-Juabeng District, Ghana. Thesis submitted to the International Institute for GeoInformation Science and Earth Observation in partial fulfillment of a Master in Science. Kwame Nkrumah University of Science and Technology.

Athula S., Scarborough H. 2011. Coping with climatic variability by rain-fed farmers in dry zone. [In:] Proc. $55^{\text {th }}$ Conf. Sri Lanka: Towards Understanding Adaptation to Climate Change. Melbourne: 8-11.

Ayers M.J., Huq S. 2008. The value of linking mitigation and adaptation: A case study of Bangladesh. Environ. Manag., 43: 753-764.

Baatuuwie N.B., Le Q.B., Agyare A.W., Forkuo K.E. 2017. Communities' Perceptions of Land Degradation: A Case Study in the Savanna Belt of the White Volta Basin. Int. J. Dev., 3, 2: 32-50.

Baccini A., Goetz S.J., Walker W.S., Laporte N.T., Sun M., SullaMenashe D., Hackler J., Beck P.S.A., Dubayah R., Friedl M.A., Samanta S., Houghton R.A. 2012. Estimated carbon dioxide emissions from tropical deforestation improved by carbon-density maps. Nature Climate Change, 2. DOI: 10.1038/NCLIMATE1354.

Baker T.R., Phillips O.L., Malhi Y., Almeida S., Arroyo L., Di Fiore A., Erwin T., Higuchi N., Killeen T.J., Laurance S.G., Laurance W.F., Lewis S.L., Monteagudo A., Neill D.A., Vargas P.N., Pitman N.C., Silva J.N., Martínez R.V. 2004. Increasing biomass in Amazonian forest plots. Philos. Trans. R. Soc. Lond. B. Biol. Sci., 359(1443): 353-65.

Bala G., Caldeira K., Wickett M., Phillips T.J, Lobell D.B., Delire C., Mirin A. 2007. Combined climate and carbon-cycle effects of large-scale deforestation. Proc. Natl. Acad. Sci. U.S.A. 104(16): 6550-6555. DOI:10.1073/pnas.0608998104.

Beauchamp T.L., Childres J.F. 2001. Principles of Biomedical ethics. 5th ed., Oxford Univ. Press, Oxford.

Bendorf R., Federici S., Forner C., Pena N., Rametsteiner E., Sanz M., Somogyi Z. 2007. Including land use, land-use change and forestry in future climate change agreements: thinking outside the box. Environ. Sci. Policy, 10: 283-94.

Bernard H.R. 2002. Research methods in anthropology: Qualitative and quantitative approaches. 3rd ed. Walnut Creek, CA: Alta Mira Press.

Betts R.A., Cox P.M., Collins M., Harris P.P., Huntingford C., Jones C.D. 2004. The role of ecosystem-atmosphere interactions in simulated Amazonian precipitation decrease and forest dieback under global climate warming. Theor. Appl. Clim., 78, 157. https://doi.org/10.1007/s00704-0040050-y.

Blay D., Appiah M., Damnyag L., Dwomoh F.K., Luukkanen O., Pappinen A. 2007. Involving local farmers in rehabilitation of degraded tropical forests: Some lessons from Ghana. Environ. Dev. Sustain. Springer. DOI:10.1007/s10668006-9077-9.

Boucher D.H, Elias P., Lininger K., May-Tobin C., Roquemore S., Saxon E. 2011. The Root of the Problem: What's Driving Tropical Deforestation Today? Cambridge, MA: Union of Concerned Scientists.

Brown H.C.A., Pentsil M.Y., Torgbor B.A., Appah J., Bosompem K.P., Frimpong Y., Gyambrah T. 2016. Ghana forest plantation strategy: 2016-2040. Minister for Lands and Natural Resources.

Bureau of Integrated Rural Development. 2001. "Tropenbos Ghana Programme Research site community survey (final report), KNUST, Kumasi".

Bush M.B., Silman M.R., Urrego D.H. 2004. 48,000 years of climate and forest change in a biodiversity hot spot. Science, 303(5659): 827-9.

Byg A., Salick J. 2009. Local perspectives on a global phenomenon - climate change in eastern Tibetan villages. Global Environ. Change, 19: 156-166.

Canadell F.G., Raupach M.R. 2008. Managing Forests for Climate Change Mitigation. Science, 320: 1456. DOI: 10.1126/science.1155458.

Canadell J.G., Le Quéré C., Raupach M.R., Field C.B., Buitenhuis E.T., Ciais P.F., Conway TJ., Gillett NP., Houghton H.R.A., Marland G. 2007. Contributions to accelerating atmospheric $\mathrm{CO} 2$ growth from economic activity, carbon intensity, and efficiency of natural sinks. Proc. Natl. Acad. Sci. U.S.A., 104, 18866. DOI: 10.1073/ pnas.0702737104.

Carvalhoa T.S., Dominguesb E.P., Horridge J.M. 2017. Controlling deforestation in the Brazilian Amazon: Regional economic impacts and land-use change. Land Use Policy, 64: 327-341. http://dx.doi.org/10.1016/j.landusepol.2017.03.001.

Chaudhary P., Bawa K.S. 2011. Local perceptions of climate change validated by scientific evidence in the Himalayas. Biology Letters, 7(5): 767-770. DOI: 1098/rsbl.2011.0269.

Chaudhary P., Rai S., Wangdi S., Mao A., Rehman N., Chhetri S., Bawa K.S. 2011. Consistency of local perceptions of 
climate change in the Kangchenjunga Himalayas landscape. Current Science, 101: 1-10.

Cheng C.K.M., Chan J.C.L. 2012. Impacts of land use changes and synoptic forcing on the seasonal climate over the Pearl River Delta of China. Atm. Environ., 60: 25-36.

Christensen J H et al., 2007. The Physical Science Basis. Contribution of Working Group I to the Fourth ssessment Report of the Intergovernmental Panel on Climate Change. Solomon S.D. et al.., (eds.) Cambridge Univ. Press, Cambridge and New York, chap. 11.

Clarke J. 1991. Moral dilemmas in Nursing Research. Nursing Practice, 4(4): 22-25.

Codjoe S.N.A., Owusu G. 2011. Climate change/variability and food systems: Evidence from the Afram Plains, Ghana. Reg. Environ. Change, 11: 753-765.

Conde C., Ferrer R.M., Gay C., Araujo R. 2004. Impactos del cambio climático en la agricultura en México. [In:] Martínez J., Fernández A. (eds) Cambio climático. Una visión desde México. Instituto Nacional de EcologíaSecretaría del Medio ambiente y Recursos Naturales, México: 227-233.

Creswell J. 2003. Research design: Qualitative, quantitative and mixed methods approaches. 2nd ed. Thousand Oaks, CA: SAGE Publ.

Dale V.H., Joyce L.A., McNulty S., Neilson R.P. 2000. The interplay between climate change, forests, and disturbances. Science Total Environ., 262: 201-204.

Dale V.H., Joyce L.A., Mcnulty S., Neilson R.P., Ayres M.P., Flannigan M.D., Hanson P.J., Irland L.C., Lugo A.E., Peterson C.J., Simberloff D., Swanson F.J., Stocks B.J., Wotton B.M. 2001. Climate Change and Forest Disturbances. Bio Science, 51(9): 723-734. DOI: http://dx.doi.org/10.1641/0006-3568(2001) 051[0723:CCAFD]2.0.CO,2.

Damptey P., Mensah A.T. 2008. Climate Change Impacts on Women's Livelihoods. The Netherlands Climate. Assistance Programme: Accra, Ghana.

Egbe C.A., Yaro M.A., Okon A.E., Bisong F.E. 2014. Rural Peoples' Perception to Climate Variability/Change in Cross River State-Nigeria. J. Sustain. Dev., 7, 2. ISSN 19139063 E-ISSN 1913-9071.

Etikan I., Musa S.A., Alkassim R.S. 2016. Comparison of Convenience Sampling and Purposive Sampling. Am. J. Theoretical Appl. Stat., 5(1): 1-4. DOI: 10.11648/j.ajtas. 20160501.11.

FAO (Food and Agricultural Organization) 2005. FAO Statistical database 2005 available at http://faostat.fao.org/.

FAO (Food and Agriculture Organization) 2007. Adaptation to Climate Change in Agriculture, Forestry and Fisheries: Perspective, Framework and Priorities, FAO InterDepartmental Working Group on Climate Change: Rome, Italy.

FAO (Food and Agriculture Organization) 2009. The State of Food Insecurity in the World 2008, Rome, Italy.

FAO Global Forest Resource Assessment 2005. Food and Agriculture Organization of the United Nations, Rome, 2006.

Fergusson H.B. 2009. REDD in Madagascar: An Overview of Progress, Independent Report, 5th November 2009. http:// www.mwc-info.net/en/services/Journal_PDF's/Issue4-2/ MCD_2009_vol4_iss2_REDD_Supplementary_Material.pdf

Ferraro P.J. 2002. The local costs of establishing protected areas in low-income nations: Ranomafana National Park, Madagascar. Ecol. Econ., 43(2-3): 261-275.

Fisher R.J. 1995. Collaborative management of forest for conservation and development issues in forest conservation. IUCN, Gland, Switzerland.

Ford L., Reutter L. 1990. Ethical dilemmas associated with small samples. J. Adv. Nursing, 15: 187-191.
Fouka G., Mantzorou M. 2011. What are the Major Ethical Issues in Conducting Research? Is there a Conflict between the Research Ethics and the Nature of Nursing? Health Sci. J., 5, 1.

Franklin J F et al. 1992. Effects of global Climatic Change on forests in northwestern North America. [In:] Peters R.L., Lovejoy T.E. (eds). The Consequences of the Greenhouse Effect for Biological Diversity. Yale University Press, New Haven (CT): 244-257.

Geist H., Lambin E. 2001. What drives tropical deforestation? A meta-analysis of proximate and underlying causes of deforestation based on subnational case study evidence Land-Use and Land-Cover Change (LUCC) Project. International Geosphere-Biosphere Programme (IGBP), LUCC Report Series: 4.

Gibbs H.K., Brown S., Niles J.O., Foley J.A. 2007. Monitoring and estimating tropical forest carbon stocks: making REDD a reality. Environ. Res. Lett., 2, 045023. DOI:10.1088/17489326/2/4/045023.

Green D., Billy J., Tapim L. 2010. Indigenous Australians' knowledge of weather and climate. Clim. Change, 100: 337-354. DOI:10.1007/s10584-010-9803z.

GSS (Ghana Statistical Service) 2014. "2010 Population and Housing Census. District Analytical Report, Ejisu-Juaben Municipal Assembly".

Gullison R.E. et al. 2007. Tropical Forests and Climate Policy. Science, 316: 985-986. 10.1126/science.1136163.

Hageback J., Sundberg J., Ostwald M., Chen D., Yun X., Knutson P. 2005. Climate variability and use change in Danangou Watershed, China - Examples of small-scale farmers adaptation. Clim. Change, 72: 189-212. DOI: 10.1007/s 10584-005-5384-7.

Hall J.B., Swaine M.D. 1981. Distribution and ecology of vascular plants in a Tropical Rain Forest Vegetation in Ghana. Geobotany, 1. The Hague: W. Junk Publ., The Hague.

Haque A., Yamamoto S.S., Malik A.A., Sauerborn R. 2012. Households' perception of climate change and human health risks: A community perspective. Environ. Health, 11: 1. http://www.ehjournal.net/content/11/1/1

Hares M., Eskonheimo A., Myllyntaus T., Luukkanen 0. 2006. Environmental literacy in interpreting endangered sustainability. Case studies from Thailand and Sudan. Geoforum, 37: 128-144.

Hawthorne W.D. 1989. The flora and vegetation of Ghana's forests. [In:] Ghana forest inventory proceedings. Overseas Development Agency/Ghana Forestry Department, Accra: 8-13.

Henderson-Sellers A., Gornitz V. 1984. Possible Climatic Impacts of Land Cover Transformations With Particular Emphasis On Tropical Deforestation. Clim. Change, 6: 231-257. 0165 -0009/84/0063-0231 \$04.05.

Hosonuma N., Herold M., De Sy V., De Fries R.S., Brockhaus M., Verchot L., Angelsen A., Romijn E. 2012. An assessment of deforestation and forest degradation drivers in developing countries. Environ. Res. Lett., 7, 044009. 1748-9326/12/ $044009 \mathrm{C} 12 \$ 33.00$.

Houghton R.A. 2008. In: Encyclopedia of Ecology. 1st edn. Jorgensen S.E. Fath B.D. (eds) Elsevier: 448-453.

IPCC (Intergovernmental Panel Climate Change) 2007. Climate Change: Impacts, Adaptation and Vulnerability. Cambridge Univ. Press, New York.

IPCC (Intergovernmental Panel Climate Change) 2014. Climate change impacts, adaptation, and vulnerability," Contribution of Working Group II to the Fifth Assessment Report, Cambridge University Press, Cambridge, UK.

IPEA (Instituto de Pesquisa Econômica Aplicada) 2011. Código florestal: implicac ões do PL 1876/99 nas áreas de reserva legal. Comunicados do IPEA. n. 96. 
Israel M., Hay I. 2006. Research Ethics for Social Scientists: Between Ethical Conduct and Regulating Compliance. Pine Forge Press, London, UK.

IUCN 2006. Forest landscape restoration to meet Ghana's deforestation Challenges. IUCN (http://www.IUCN.org/ en/news/archive/2006/newfebruary06.htm)

Katz E., Goloubinoff M., Lammel A.M. 1998. El niño visto por las ciencias sociales: propuesta de investigación. Bull. Inst. Fr. Etudes Andines, 27(3): 857-864.

Kioko J., Kiringe J.W., Seno S.O. 2012. Impacts of livestock grazing on a savanna grassland in Kenya. J. Arid Land 4(1): 29-35.

Kioko J., Okello M.M. 2010. Land use cover and environmental changes in a semi-arid rangeland, Southern Kenya. J. Geogr Regional Plan., 13(11): 322-326.

Klooster D. 2003. Forest Transitions in Mexico: Institutions and Forests in a Globalized Countryside. The Professional Geographer, 55(2): 227-237.

Lammel A., Goloubinoff M., Katz E. 2008. Aires y lluvias. Antropología del clima en México. CIESAS/CEMCA/IRD, México.

Lawrence A. (ed.) 2000. Forest, forest users and research: New ways of learning. [In:] Proc. workshop, "Learning from resources users-a paradigm shift in tropical forestry". Vienna, Austria. ETFRN, Wageningen.

Lazos E., Paré L. 2000. Miradas indígenas sobre una naturaleza entristecida. Percepciones del deterioro ambiental entre nahuas del sur de Veracruz. Instituto de Investigaciones Sociales-UNAM/Plaza y Valdés, México.

Leduc T.B. 2007. Sila dialogues on climate change: Inuit wisdom for a cross-cultural interdisciplinarity. Clim. Change, 85: 237-250. DOI:10.1007/s10584-006-9187-2.

Lobell D.B., Field C.B. 2007. Global scale climate-crop yield relationships and the impacts of recent warming. Environ. Res. Lett., 2, 014002.

Locatelli B., Kanninen M., Brockhaus M., Colfer C.J.P., Murdiyarso D., Santoso H. 2008. Facing an Uncertain Future: How Forests and People Can Adapt to Climate Change. Center for International Forestry Research (CIFOR): Bogor, Indonesia.

Macchi M., Gurung A.M., Hoermann B. 2014. Community perceptions and responses to climate variability and change in the Himalayas. Climate Dev., DOI: 10.1080/17565529. 2014.966046.

Macchi M., ICIMOD Team. 2010. Mountains of the world ecosystem services in a time of global and climate change. Kathmandu: ICIMOD.

Malhi Y., Grace J. 2000. Tropical forests and atmospheric carbon dioxide. Trends Ecol. Evolut., 15: 332-337.

Malhi Y., Roberts J.T., Betts R.A., Killeen T.J., Li W., Nobre C.A. 2008. Climate Change, Deforestation, and the Fate of the Amazon. Science, 319, 169. DOI: 10.1126/science. 1146961.

Metz B., Davidson O., Bosch P., Dave R., Meyer L. (eds) 2007. Climate Change 2007 Mitigation. Cambridge Univ. Press, Cambridge: 541-584.

Ministry of Lands and Natural Resources 2012. Climate Investment Funds Forest Investment Program. Ghana Investment Plan for the Forest Investment Program. https://www.fcghana.org/assets/file/Programmes/Fore st_Investment_Plan_fip/Ghana\%20Draft\%20FIP\%2035\%20_31_august2012.pdf on September 4, 2017.

Morara M.K., MacOpiyo L., Kogi-Kamau W. 2014. Land use land cover change in urban pastoral interface. A case of Kajiado County, Kenya. J. Geogr. Regional Plan., 7(9): 192-202.

NDPC (National Development Planning Commission) 2015. Depletion of forest cover continues at alarming rate Report. http://www.ghananewsagency.org/science/depletion- of-forest-cover-continues-at-alarming-rate-report96094 [Access 4.09.2017]

Nelson W., Agbey S.N.D. 2005. Linkage between Poverty and Climate Change: Adaptation of the Livelihood for the Poor in Ghana. National Development Planning Commission and Friends of the Earth Ghana: Accra, Ghana.

Oduro K A et al.., 2012. Ghana Forest and Wildlife Handbook. Ghana Forest and Wildlife Resources, 2012: A compendium of information about forests and wildlife resources, forestry related issues and wood processing in Ghana.

Oldeman D.C., Hakkeling T.A., Sombrock W.G. 1991. World Map of the Status of Human Induced Soil Degradation: An Explanatory Note. The Netherlands and Nairobi International Soil Reference and Information Centre and UN environment program.

Olsson P., Galaz V., Boonstra W.J. 2014. Sustainability transformations: a resilience perspective. Ecology and Society, 19(4): 1. http://dx.doi.org/10.5751/ES-06799190401

Orlove B.S., Chiang J.H., Cane M.A. 2000. Forecasting Andean rainfall and crop yield from the influence of El Niño on Pleiades visibility. Nature, 403: 68-71.

Orlove B.S., Chiang J.H., Cane M.A. 2002. Ethnoclimatology in the Andes: a cross-disciplinary study uncovers the scientific basis for the scheme Andean potato farmers traditionally use to predict the coming rains. Am Sci., 90: 428-435.

Orlove B.S., Tosteson J.L. 1999. The Application of Seasonal to Interannual Climate Forecasts Based on El Niño Southern Oscillation (ENSO) Events: Australia, Brazil, Ethiopia, Peru, and Zimbabwe. Institute of International Studies. Berkeley Workshop on Environmental Politics. http://repositories.cdlib.org/iis/bwep/WP99-3-Orlove

Ostrom E. 1999. Self Governance and Forest Resources. Center for International Forestry Research (CIFOR) Discussion paper No. 20.

Owusu K., Waylen P., Qiu Y. 2008. Changing rainfall inputs in the Volta basin: implications for water sharing in Ghana. GeoJournal, 71: 201-210.

Oyama M.D., Nobre C.A. 2003. A new climate-vegetation equilibrium state for Tropical South America. Geophys. Res. Let., 30, 2199. DOI: 10.1029/2003GL018600.

Palys T. 2008. Purposive sampling. [In:] Given L.M. (ed.) The Sage Encyclopedia of Qualitative Research Methods. Vol. 2. Sage: Los Angeles: 697-8.

Patton M.Q. 2002. Qualitative research and evaluation methods. 3rd ed. Thousand Oaks, CA: Sage.

Peprah P., Abalo E.M., Amoako J., Nyonyo J., Agyemang-Duah W., Adomako I. 2017. "The Reality from the Myth": The poor as main agents of forest degradation: Lessons from Ashanti Region, Ghana. Environ. Socio-econ. Stud., 5, 3: 111. DOI: $10.1515 /$ environ-2017-0011.

Prah E.A. 1997. Joint forest management - the Gwira-Banso experience. Commonwealth Forestry Rev., 76(3): 171-174.

Rahman H., Alam K. 2016. Forest Dependent Indigenous Communities' Perception and Adaptation to Climate Change through Local Knowledge in the Protected Area - Bangladesh Case Study. Climate, 4, 12. DOI:10.3390/cli4010012.

Ramankutty N., Gibbs H.K., Achard F., DeFries R., Foley J.A., Houghton R.A. 2007. Challenges to estimating carbon emissions from tropical deforestation. Glob. Change Biol., 13: 51-66. DOI: 10.1111/j.1365-2486.2006.01272.x.

Ratsimbazafy C.L., Harada K. Yamamura M. 2012. Forest resources use, attitude, and perception of local residents towards community based forest management: Case of the Makira Reducing Emissions from Deforestation and Forest Degradation (REDD) Project, Madagascar. J. Ecology Natural Environ., 4(13): 321-332: DOI: 10.5897/JENE11.123. 
Raupach M.R., Marland G., Ciais P., Le Quéré C., Canadell J.G., Klepper G., Field C.B. 2007. Global and regional drivers of accelerating $\mathrm{CO} 2$ emissions. Proc. Natl. Acad. Sci. U.S.A. 104, 10288. DOI: $10.1073 /$ pnas.0700609104.

Repetto R. 1988. The forest for trees? Government policies and the misuse of forest resources. Washington $\mathrm{DC}$, World Resources Institute.

Repetto R. 1990. Deforestation in the tropics. Sc. Am., 262: $36-42$.

Ringrose S., Chanda R., Nikambwe M., Sepe I. 1996. Environmental change in the Mid-Boteti area of North Central Bostwana: biophysical process and human perceptions. Environ Manage, 20(3): 397-410.

Roberstson J., Lawes M. 2005. User Perceptions of Conservation and Participatory Management of Igxalingenwa Forest, South Africa. Environ. Conserv., 32(1): 64-75.

Roy S.B., Avissar R. 2002. Impact of land use/land cover change on regional hydrometeorology in Amazonia. $J$. Geophys. Res., 107. 8037. DOI: 10.1029/2000JD000266.

RSAS 2002. The Abisko agenda: Research for mountain area development. Ambio Special Report 11. Stockholm.

Sabine C.L. et al. 2004. In: Global Carbon Cycle: Integrating Humans, Climate and the Natural World. Field C., Raupach M. (eds.) Island Press, Washington, DC: 17-44.

Sánchez-Cortés M.S., Chavero E.L. 2011. Indigenous perception of changes in climate variability and its relationship with agriculture in a Zoque community of Chiapas, Mexico. Clim. Change, 107: 363-389. DOI: 10.1007/s10584-010-9972-9.

Scherl L.M., Wilson A., Wild R., Blockhus J., Franks P., McNeely J.A., McShane T.0. 2004. Can Protected Areas Contribute to Poverty Reduction? Opportunities and Limitations. Chief Scientist's Office Report, IUCN, Gland.

Seppälä R., Buck A., Katila P. 2009. Adaptation of Forests and People to Climate Change - A Global Assessment Report. International Union of Forest Research Organizations (IUFRO): Helsinki, Finland.

Stephens B.S. et al. 2007. Weak Northern and strong tropical land carbon uptake from vertical profiles of atmospheric $\mathrm{CO}_{2}$. Science, 316: 1732-5.

Stigter C.J., Dawei Z., Onyewotu L.O.Z., Xurong M. 2005. Using traditional methods and indigenous technologies for coping with climate variability. Clim. Change, 70: 255-271.

Stocking M., Murnaghan N. 2001. Handbook for the field assessment of Land Degradation. Earthscan Publ., London.

Tashakkori A., Teddlie C. (eds.) 2003. Handbook of mixed methods in social and behavioral research. Thousand Oaks, CA: Sage.

Teddlie C., Yu F. 2007. Mixed Methods Sampling: A Typology with Examples. J. Mixed Methods Res., 1, 77. DOI: 10.1177/ 2345678906292430.

Thomas D.S.G., Twyman Ch., Osbahr H., Hewitson B. 2007. Adaptation to Climatic Change and variability: farmer responses to intra-seasonal precipitation trends in South Africa. Clim. Change 83: 301-322. DOI:10.1007/s10584006-9205-4.

Tinker P.B., Ingram J.S.I., Struwe S. 1996. Effects of slash-andburn agriculture and deforestation on climate change. Agr. Ecosystems Environ., 58: 13-22. SSDI 0167-8809(95)00651-6.

UNDP (United Nations Development Programme): In: Human Development Report 2007. Background Paper on Risks,
Vulnerability and Adaptation in Bangladesh. Rahman A., Alam M., Alam S.S, Rabi Uzzaman M., Rashid M., Rabbani G. (eds.). Dhaka: UNDP: 1-86.

UNEP 1997. World Atlas of Desertification. (2nd edn), Middleton N., Thomas D.S.G. (eds). Edward Arnold: London.

UNFCCC (United Nations Frame Work Convention on Climate Change) 1992. Rio de Janeiro, Brazil. http//www. unfccc. int/text/ resources/docs/convkp/conveng.pdf.

UNFCCC (United Nations Framework Convention on Climate Change) 2009. "Fact Sheet: The Need for Mitigation," available at unfccc.int.

UNFCCC 2009. Methodological guidance for activities relating to reducing emissions from deforestation and forest degradation and the role of conservation, sustainable management of forests and enhancement of forest carbon stocks in developing countries Decision COP 15/4 (http://unfccc.int/resource/docs/2009/cop15/eng/11a01. pdf\#page=11).

UNFCCC 2010. Outcome of the work of the ad hoc working group on long-term cooperative action under the convention-policy approaches and positive incentives on issues relating to reducing emissions from deforestation and forest degradation in developing countries: and the role of conservation, sustainable management of forests and enhancement of forest carbon stocks in developing countries UNFCCC COP 16 Cancun (http://unfccc.int/ 2860.php).

USAID (United States Agency for International Development) 2006. Issues in Poverty Reduction and Natural Resource Management. Washington, DC.

van der Werf G.R., Morton D.C., DeFries R.S., Olivier J.G.J., Kasibhatla P.S., Jackson R.B., Collatz G.J., Randerson J.T. 2009. CO2 emissions from forest loss. Nature Geoscience, 2: 737-738.

Vardeman S., Morris M. 2003. Statistics and ethics. The American Statistician, 57(1): 21-26.

Vedwan N., Rhoades R. 2001. Climate change in the western Himalayas of India: A study of local perception and response. Clim. Res., 19: 109-117.

Wagner M.R., Cobbinah J.R. 1993. Deforestation and sustainability in Ghana: the role of tropical forests. Ghana J. Forestry, 91: 36-39.

Whyte A. 1977. Guidelines for field studies in environmental perception. MAB. Technical Notes 5. UNESCO, Paris.

Whyte A. 1985. Perception. In: Climate Impact Assessment. Studies of the interaction of climate and society. Scope 27. http://www.icsu-scope.org/downloadpubs/scope27/ chapter16.html

Wiggins S., Marfo K., Anchirinah V. 2004. Protecting the Forest or the People? Environmental Policies and Livelihoods in the Forest Margins of Southern Ghana. World Dev., 32(11): 1939-1955.

World Bank 2000. World Development Report: Attacking Poverty. World Bank, Washington DC.

World Bank 2008. Forests Sourcebook: Practical Guidance for Sustaining Forests in Development Cooperation.

World Bank 2017. The Costs to Developing Countries of Adapting to Climate Change: New Methods and Estimates. Available online: http://www.worldbank.org/eacc. [Access 2017.09.21]. 